\title{
Model of Family Education and Divorce Prevention Efforts in Sasak Tribe People in Indonesia
}

\author{
Syafruddin Syafruddin* \\ Department of Social Sciences \\ University of Mataram \\ Mataram, Indonesia \\ syafruddin_fkip@unram.ac.id
}

\author{
Hairil Wadi \\ Department of Social Sciences \\ University of Mataram \\ Mataram, Indonesia \\ wadifkipunram@gmail.com
}

\begin{abstract}
The objectives of this study is to map the model of family education and divorce prevention efforts in Sasak tribe people, in Lombok Indonesia. The research approach used is qualitative research with survey method. The results show that the model of family education programs proposed by the society was conducted with the following stages; (1) Educational Program Orientation, including: Preparation of community institutions, Resource Person Orientation, Target Object Orientation; (2) Determination of family education programs. There are 3 programs selected by the society as educational programs that can prevent the occurrence of divorce: a) Gender and Sexuality Education Program, b) Family Law Education Program, c) Pre-Marriage Counseling Education Program; and (3) Implementation of the programs. In order that the family education program implemented to prevent the occurrence of divorce, the pattern of education and family skills training, workshops and marriage consultation clinics were conducted.
\end{abstract}

Keywords - model of education, prevention of divorce, sasak tribe.

\section{INTRODUCTION}

What the outsiders impresses from the Sasak tribe people is their family institution. The family institution is considered weak and thus broken home can happen at any time and this indicates that the family life is concise. It may be different for other tribes in Indonesia, in which there are no cries of children who are abandoned by their parents or children who are cared for by orphanages in a dirty village with inadequate facilities, except for the extraordinary cases because their mothers or father passed away.

Research from Hildred (1983) and Nakamura (1990) which conducted in Java found that the high divorce rate because the average first marriage of their children is arranged by the parents, most of the Javanese women know that divorce can only be done by their husbands, but there are some cases of wives persuading their husbands to divorce them if they are bored with their marriages. If the husband refuses while the wife insists on the desire to divorce, then the wife will fight back by leaving her husband. It is in accordance with the notes made by Raffles in 1817 (Muhamad, 1998), stating that Javanese women may divorce their husbands if they feel dissatisfied with their marriage by paying the money as determined by the traditional institutions.

Research results of Bartholomew (1999) found that the occurrence of divorce in the Sasak people because there are still many marriages of suka lokaq. Suka lokaq is a marriage that arranged according to the desire of parents. According to Bartholomew, matchmaking practices were popular in the Sasak-Lombok society and recently began to decline slightly due to the development of communication and transportation. This matchmaking usually happens a lot in Sasak aristocrats to maintain their status and special privileges, and mostly conducted among the members from the same class so the candidate spouse will become a legitimate member of the nobility. The results of study conducted by Syafruddin (2010) to 525 divorce cases showed that around $78 \%$ of divorces are done at home/family, $14 \%$ are done under the acknowledgment or at the house of the Moslem leader and only $2.8 \%$ are done in the religious court. This study also found that the factors causing divorce were: $33 \%$ for infidelity, $18 \%$ for husband running away from the responsibility, $18 \%$ domestic violence, $16.9 \%$ for third person intervention and $13 \%$ for economic problems. Considering the problem of divorce on sasak society and having conducted careful analysis, in this paper the researcher will explain how the more innovative model of family education programs should be implemented and adapted to the life of rural communities.

\section{METHOD}

This research uses a qualitative research approach. Through this approach, the researchers can show the community life and kinship relationships, can create and arrange the essential concepts (Strauss and Corbin, 2004. Bodgan and Taylor, 2003). To learn deeply about divorce issues and models of family education programs in the Sasak people, researchers applied survey research methods with group as the study unit.

To check the validity of the survey data, the following activities are done: 1) triangulation of data sources conducted by finding data from many sources of respondents, informants and research subjects. 2) triangulation of data collection methods (observation, interviews, documentation studies and focus group discussions). The implementation scenario of this research to find the model of family education program is by conducting the following stages: Field survey; Identification, Processing, and Data analysis.

\section{Result AND Discussion}

In this research, the interviews were conducted on the subject, informants, and respondents amounted to 525 people. The results from the interviews showed that the approach model selected by the people to prevent divorce in the Sasak society is through the family education approach or 
programs, including e: (1) Gender education program, (2) Family law education program, (3) Pre-marital counseling education program, and (4) Family life skills program (see graphic 1).

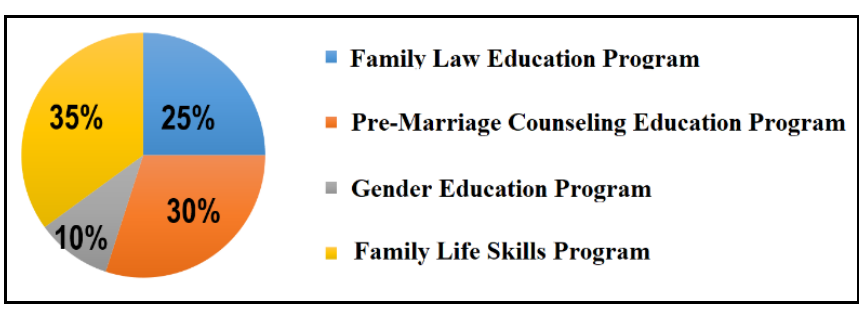

Fig. 1. Type of Education Program

Based on the findings in this study, it is found that the model and the mechanism of family education program implemented by Sasak-Lombok people including the following stages:

\section{A. The Family Educational Program Orientation}

In this stage, certain requirements need to prepared are: (a) Community institutions for the implementation of programs. The institutions selected must have a wide range and be able to represent the life of the local community. In the context of the Sasak people in Lombok island, the most popular community institution is Nahdlatul Wathon (NW), such as the Muslimat Nadhlatul Wathon group. (b) Resource Person Orientation. The orientation of the resource persons is very important to note because there is a relationship with the transference of the messages; who said what to whom, and where it is done. In Sasak-Lombok rural communities which are still vertically oriented, the concept of who says what to whom is still maintained because some certain public figures still have authority and credibility in the community. The Tuan Guru (Moslem Leaders) figure in the Sasak community is centric and charismatic because their behaviors and messages are role models for the community. Tuan Guru status can be used as an agent of social change. In addition to Tuan Guru as the role models, it is also necessary to find the experts who will deliver information about family education programs. Institutionally, the community expects direct involvement from the Office of the Ministry of Religion such as KUA and PPN. (c) Target Object Orientation Program. The main targeted objects of this activity are teenagers who have been at the age of marriage. The research results found that about $38 \%$ of divorces come from those who got marriage under their ages of 18 years. (d) Procurement of Teaching Materials. The prepared teaching materials will make it easier for them to understand the education and training programs that will be provided.

\section{B. Determination of Family Education Program}

Based on the results of the study found that there are three programs selected by the community as family education program that allows to prevent divorce in the Sasak-Lombok society, namely:

\section{1) Gender and Sexuality Education Program}

This program is important to be implemented, considering that still many divorces occur due to gender bias. Gender education is needed so that people can understand the differences between the two sexes derived from natural factors which are gifts from God, as well as factors that come from the community which constitute a social cultural construction. This program will eliminate the wrong labeling on women as wives, which hinder the occurrence of gender equality (between the husband and wife). Sex education is also important, especially relating to the reproductive health of women and men. Of the 525 identified divorce cases, it is found that around $20 \%$ of divorced couples never went to school, $18 \%$ of them did not complete primary school and only $24 \%$ of them completed primary school.

This study empirically found that the occurrence of gender inequality caused violence at home that led to divorce. The survey data show that the cause of divorce due to violence with 98 cases or $18.5 \%$, involving symbolic and physical violence.

Manifestations of symbolic violence can be related to manipulation efforts to define the reality of life conducted by dominant community group, namely men (Hendarti, 2000: 25). Galtung (2002: 11) called this as cultural violence violence on the cultural aspects, namely the existence of symbolic area such as religion and ideology, language and etc. which can be used to justify or legitimize physical and symbolic violence. Symbolic violence can also be said as violence that can injure the victim morally and psychologically.

Violence against women as wives can be in the form of physical or symbolic violence. Symbolic violence, for example, occurs in a woman who is not yet mature but she is forced to marry by her parents with a man she doesn't like or it can also happen because of a husband who likes to date with another woman, having an affair and married again which in turn can hurt the wife psychologically. From some of these cases, it is found that within the family life, the dominant group of men as husbands is the primary agent of this violence. In this case. a husband has the authority as a decision maker and has a great influence on his wife. This happens because it is supported by social, cultural, religious and legal norms within the structure of a patriarchal society.

\section{2) Family Law Education Program}

This program is important to be implemented because the research data found that the patterns of divorce conducted by the Sasak society mostly done informally, $78 \%$ is done at home, $14 \%$ is at Moslem leader home and only $2.8 \%$. is at religious court. These data provide information that the level of public awareness is still low. Divorce should be done in formal institutions such as religious affairs office and the religious court as a forum for mediation to end the marriage bond. In these institutions they know about who takes care of what, and what to get if they have children or property to be distributed, but in reality, they do not know the formal institutions that has right to terminate their marriage (divorce).

\section{3) Pre-Marriage Counseling Education Program}

Pre-marriage counseling programs can be a good alternative to strengthen the heart and mentality in dealing with household problems. By doing pre-marriage counseling programs many benefits can be obtained, including practicing the openness between partners, equalizing differences between partners, and anticipating conflict. The purpose of pre-marriage counseling programs is also to the achievement 
of satisfaction between couples, it is related to the principle of life, perception on marriage, division of tasks, finances, habits, and family.

This study found a number of cases, in which $18 \%$ of those people interviewed did divorce because the husband ran away from his responsibility. Many of their husbands went overseas to Malaysia and Arabic countries, they leave their children without adequate living expenses, in addition, many husbands leave the wives because they marry another woman in other places or regions, so that the family life is neglected. The causes of divorce are due to the neglected husband's responsibility and the occurrence of conflict in the family which indicates that the intimate relationships have led to a dangerous explosion of anger which produces feelings of hostility and every depressed feeling will add to the intensity of the hostility, and that the emotional overflow which occurs might cause a very hard and dangerous effect for a relationship (Johnson, 1988: 201, Poloma, 1987: 113). When this problem can no longer be solved by the husband as a responsibility person or the husband responsibility is neglected and can no longer fulfill basic moral obligations, the explosion of anger and conflict will spread and become hard because as a wife with instinct, heart and mind will certainly lose her temper. Divorce is an instrument that can be used and understood by them (women as wives) to determine the direction of the next life because divorce not only has a negative aspect but also has a positive side. It means that the failure of an unpleasant first marriage will be a valuable lesson to move on and to have the better marriage life in the future (Kendall, 2001. Goode, 1991).

\section{The Pattern of Activity Implementation}

The pattern of the activities proposed by the society to realize the family education program to prevent and minimize the occurrence of divorce in Sasak-Lombok society are implemented with a variety of patterns, namely: education and training patterns, workshops, and marriage consultation clinics. (Figure 2. Family Education Model to Prevent Divorce).

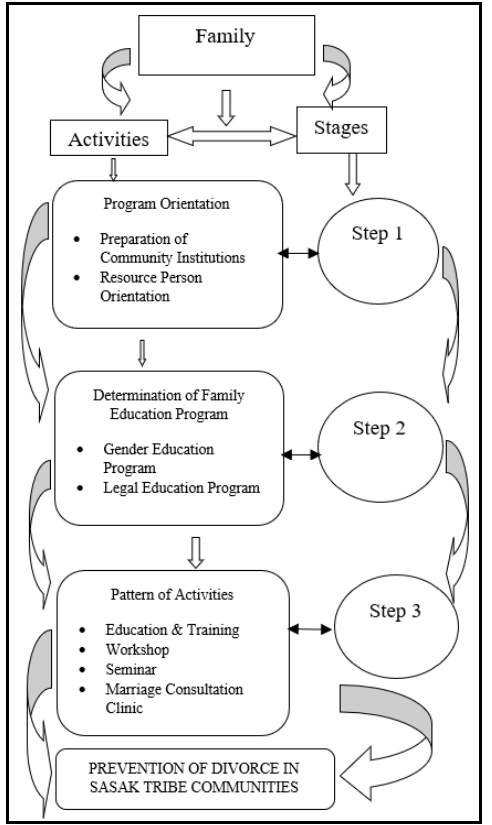

Fig. 2. Family Education Model to Prevent Divorce

\section{CONCLUSION}

The model of family education programs that can prevent divorce in the Sasak-Lombok society can be conducted in the following stages: (1) Program orientation involving preparing community institutions, resource person orientation, target object orientation and procurement of teaching materials. (2) Determination of the type of family education programs including Gender and Sexuality Education Program, Family Law Education Program, and Pre-Marriage Counseling Program. While the patterns of activities are through: education and training, workshops, and marriage consultation clinic.

Based on the model of family education programs proposed by the society, the findings of this study can be used as a guideline for the related parties, especially for the Ministry of Religion of the Republic Indonesia (religious department and religious courts) to compile family education programs that emphasize on understanding of the laws relating to family law and family education programs which are oriented towards partnership between men and women. In addition, the more important thing is the institutionalization of the marriage consultation clinic program to the rural areas or villages.

\section{REFERENCES}

[1] Geertz, Heldred. Keluarga Jawa (terj). Jakarta: Grafiti Press. 1983

[2] Nakamura, Hisako. Perceraian dalam Masyarakat Jawa. Yogyakarta: Gajah Mada press. 1990

[3] Muhamad, Kartono. Kontradiksi dalam Kesehatan Reproduksi. Jakarta: Pustaka Sinar Harapan. 1998

[4] Bartholomew, Ryan John. Alif Lam Min, Kearifan Masyarakat Sasak. Yogyakarta: Tiara wacana. 1999

[5] Syafruddin, Sumardi, Sukardi. Pengembangan Model Pendidikan Keluarga Melalui Kelompok Muslimat NW (Nahdlatul Wathon) Sebagai Upaya Mencegah Terjadinya Perceraian pada Masyarakat sasak Lombok (laporan penelitian). Mataram: LPPM Universitas Mataram. 2010

[6] Strauss, Amselm and Juliet Corbin. Dasar-dasar Penelitian Kualitatif, prosedur, Teknik, dan Teori Grounded (terj). Surabaya: Bina Ilmu. 1997

[7] Bodgan, Robert dan Steven Taylor,. Kualitatif Dasar-Dasar Penelitian. Surabaya: Usaha Nasional Surabaya. 1993

[8] Hendarti M, Ignatia. "Kekerasan Simbolik: Protes Terselubung dalam Cerita Fiksi Populer Wanita indonesia". Dalam Jurnal RENAI, Edisi oktober 2000-Maret 2001, tahun I, No. 1. Salatiga: Pustaka Percik. 2000 .

[9] Galtung, Johan. "Kekerasan Kultural". Dalam Jurnal Ilmu Sosial Transformatif. Edisi 9, thn III. Yogyakarta: Insist Press. 2002

[10] Johnson P, Doyle. Teori Sosiologi Klasik dan Modern, jilid 1 dan 2 (terj). Jakarta: Gramedia. 1988

[11] Poloma, M. Margaret. Sosiologi Kontemporer. Jakarta: CV. Rajawali. 1987

[12] Kendall, Diana. Sosiology in Our Times. Singapure: wadsworth. 2001

[13] Goode, J, William,. Sosiologi Keluarga (terj). Jakarta: Bina Aksara. 1991 